\title{
Analysis of Pump Factory Supplier Selection Criteria Using AHP Method (Pt. XYZ Jakarta)
}

\author{
Khoirul Akbar Etlanda and Ahmad Hidayat Sutawidjaya
}

\section{ABSTRACT}

This study was structured to analyze the selection of suppliers at PT. XYZ (JAKARTA) which is a pump manufacturing company based in Jakarta. The object of this research is the management of PT. XYZ (JAKARTA). There are five criteria that have been determined by the management of PT. XYZ (JAKARTA), Price, Service, Company Condition, Quality and Delivery. Each criterion has also been determined sub-criteria to be more specific in the selection. Respondents for this study were managers and assistant managers who were directly related to the production process at PT. XYZ (JAKARTA). Determination of supplier selection criteria is calculated based on the weight of the criteria and the weight of the sub-criteria; the weighting of these criteria is carried out through the Analytical Hierarchy Process method. From the research results obtained the main criteria in the selection of suppliers are Quality, Delivery, Company Condition, Service and Price. The Consistency Ratio value of the five main criteria is at the tolerance limit $(0.1)$, which states that the respondents' answers are included in the valid and consistent category.
Submitted : December 29, 2021

Published : February 22, 2022

ISSN: 2507-1076

DOI: $10.24018 /$ ejbmr.2022.7.1.1231

\section{Khoirul Akbar Etlanda*}

Mercu Buana University, Indonesia. (e-mail: khoirulakbaretlanda ${ }^{\circledR}$ gmail.com) Ahmad Hidayat Sutawidjaya Mercu Buana University, Indonesia. (e-mail: a.h.sutawijaya ${ }^{\circledR}$ mercubuana.ac.id)

*Corresponding Author

Keywords: Analytical Hierarchy Process, Consistency Ratio, Supplier.

\section{INTRODUCTION}

Indonesia is an agricultural country that has a lot of natural wealth, equipped with abundant natural resources that still need to be managed in order to become a selling point. This has attracted the interest of companies that support agricultural needs to establish their companies in Indonesia, one of which is a pump company from Japan, namely PT. XYZ (Jakarta).

PT. XYZ (Jakarta) is a manufacturing company that produces pumps, used for industry, buildings, flood control and even for agriculture. This company was founded in Indonesia in 1980 which is a collaboration between a Japanese company and a local company in Indonesia. This company was born as the first pump company equipped with metal casting fabrication. This company was founded with the main target to support the Indonesian economy. Indonesia, which is an agrarian country and has a huge market opportunity to use pumps and PT. XYZ (Jakarta) has the opportunity to dominate the Indonesian market. To meet the demand for pumps in Indonesia, the Company is equipped with a production capacity that is estimated to be able to produce around 3500 pump units per month. PT. XYZ (Jakarta) began to get additional orders from Southeast Asia, the Middle East and even to Europe, this required PT. XYZ (Jakarta) to increase production capacity. This is also reinforced by the onset of delays in delivery to customers, which is the effect of the surge in orders received by PT. XYZ (Jakarta)

Delivery delays often have an impact on fines that will be borne by the company. Indeed, not all orders have the consequence of a fine, but in some cases a fine has been given if the delivery is late. This of course will make a loss for PT. XYZ (Jakarta), which forces the company to be able to meet the demands of these customers.

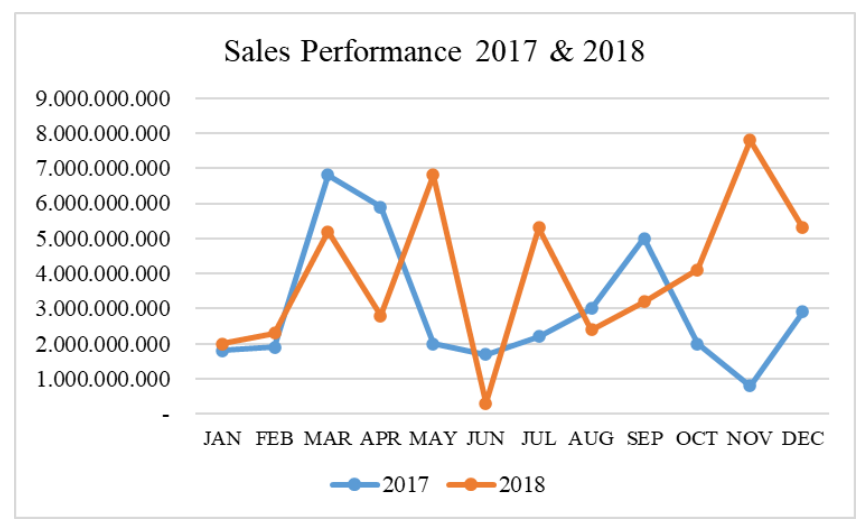

Fig. 1. Sales Data in 2017 and 2018. Source: Primary Data. (2020).

In sales data in 2017 and 2018 it shows an increase in sales of PT. XYZ (Jakarta), namely the achievement in 2017 was Rp. 34 billion and in 2018 it was Rp. 47 billion. This increase was also accompanied by a number of pump-ordered, this is what causes lead time delivery becomes longer. One way to increase customer satisfaction regarding delivery is by accelerating production by reducing production lead time. The smaller the lead time, the production target to be achieved is expected to be larger than before. To be able to follow the lead time acceleration, it is necessary to work effectively and prepare all suppliers involved in the production process.

In general, product workmanship at PT. XYZ (Jakarta) is divided into two, namely metal casting work and purchase parts. Metal casting work is carried out in the PT. XYZ 
(Jakarta) starts from raw material preparation, mold preparation, and casting process. After the casting production process is complete, the cooled casting components will go through the grinding process to be smoothed and go through the basic painting process, then proceed with the machining process to be shaped and smoothed based on the drawings that have been made, after the machining process, the components will enter the warehouse to wait assembly process.

Purchase part, this process is carried out at the supplier, so that all processes of material preparation until the goods are ready to be used are carried out at the supplier's place. To be able to improve the delivery of shipments to customers, of course, cooperation between PT. XYZ (JAKARTA) and its suppliers, it is necessary to review the supply chain process, so that it can be an improvement material for PT. XYZ (JAKARTA) and its suppliers.

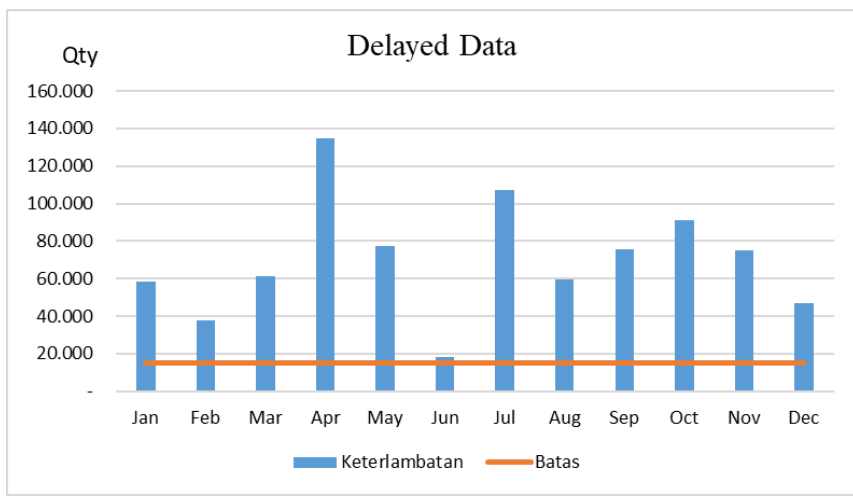

Fig. 2. Example of Delay Data by Supplier. Source: Primary Data. (2020).

The data above shows examples of delays in delivery that occurred from the supplier PT. XYZ (Jakarta), from this data we can find out the number of days of delay from the supplier. Data delivery supplier as a whole showed a delay in delivery of parts from suppliers, delivery delays are discrepancies delivery schedules supplier with the delivery schedules proposed by PT. XYZ (Jakarta), the schedule submission is adjusted to the assembly process schedule at PT. XYZ (Jakarta), with the meaning that if there is a delay in the process, there will be a delay in the assembly schedule , and will result in a delay in delivery to PT. XYZ (Jakarta). In 2017 , deliveries from suppliers on time were $73 \%$ and delays were $27 \%$, while in 2018 there has been an increase in ontime deliveries to $76 \%$ and delays by $24 \%$.

The delay in support from the supplier affects the delivery of PT. XYZ (Jakarta) to customers. This is reinforced by the existence of customer delivery data which shows delays. Delivery data to customers has a higher percentage of delays compared to delivery suppliers to PT. XYZ (Jakarta), this is because 1 pump unit is supported by several suppliers, so that if the purchase part is delayed from several suppliers, it will cause a longer delay in the pump unit. The data shows an improvement or change in the percentage of on time delivery that is better than 2017, but this does not provide significant results on delivery to customers. PT. XYZ (Jakarta) expects no delays from suppliers so that the company can deliver pumps to customers on time.

With the large percentage of delays from suppliers, PT. XYZ (Jakarta) needs to evaluate, so that delivery to customers is improved for the better. Companies must review the supply chain process from suppliers to find out the effectiveness of their work and companies need to know again the criteria for suppliers that can meet their needs. So that the company's goals can be achieved properly. Supplier selection criteria have a direct impact on company productivity, this is because raw materials and purchase parts are the most important factors in the production process to produce optimal products. To support the smoothness of the production process, PT. XYZ (Jakarta) must know in advance the most important criteria that can be used as benchmarks in supplier selection.

From the phenomena above, the author conducted a study entitled "Analysis of the Selection Criteria for Pump Factory Suppliers with the AHP Method" a case study at PT. XYZ (Jakarta).

\section{THEORY}

\section{A. Supply Chain Management}

Supply Chain Management is the management of complementary cycle chains starting from raw materials to company operations, to distribution to consumers. Supply chain management was introduced in 1982, this idea was conveyed by Oliver and Weber. Supply chain is a physical network, which connects companies that supply (raw products), activities produce goods, or send them to customer, supply chain management is a method, tool, management approach.

James A and Mona $\mathrm{J}$ also conveyed the understanding of Supply Chain Management, they said supply chain management is a comprehensive approach to delivering products to customers through the use of information technology to coordinate supply chain elements starting from suppliers to retailers, so as to reach the next level. This is a competitive advantage not available in traditional logistics systems.

At the same time, Chase, Aquilano, and Jacobs define supply chain management as a system that applies a holistic approach to managing all information, materials, and services from raw materials to factories and warehouses to final consumers. Then Robert J. Vokurka, Gail M. Zank and Carl M. Lund III came to their conclusion that supply chain management is all activities in the delivery of products from raw materials through customers, as well as raw materials. sourcing of parts, manufacturing and assembly processes, warehousing, purchase orders and order management, distribution across all channels, shipping to all customers, and information systems needed to monitor all ongoing activities.

The definition of supply chain management is also conveyed by Stevenson, Stevenson argues that supply chain management as strategic coordination in the supply chain aims to integrate all supply and demand management. Russell and Taylor define supply chain management as ways to manage the flow of information, products and services throughout the customer network, from the company to the supplier. Supply Chain Management includes the determination of the following:

1. Transportation;

2. Payment in cash or credit / (Term of Payment);

3. Supplier;

4. Distributors and parties that facilitate transactions;

5. Debts and receivables; 

6. Inventory;
7. Order Fulfillment;
8. Information about casting, production.

\section{B. Supply Chain Management Model}

The supply chain management model was proposed by Indrajit and Djokopranoto in 2002. They explained that the main participants who are interested in the flow of goods can be developed through the supply chain model, namely a plastic picture of the relationship between the supply chain and these participants can be formed into an interconnected chain. complementary relationship of several companies or organizations that collectively collect, purchase, convert, and distribute goods or services to final customers. The key factor in supply chain optimization is the creation of an easy and accurate flow of information between networks or between links, as well as effective and efficient movement of goods, so that maximum satisfaction is obtained. The loop can be described as follows:

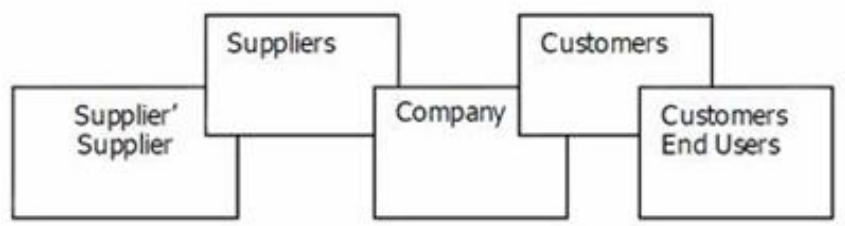

Fig. 3. Supply Chain Management Model according to Indrajit and Djokopranoto. Source: Indrajit and Djokopranoto (2002).

James A. and Mona J. According to Fitzsimmons (2006), a physical item in the supply chain can be identified as a stage in the material value network, each determined by input supply, material conversion, and demand output. Below is a supply chain diagram of a commodity product.

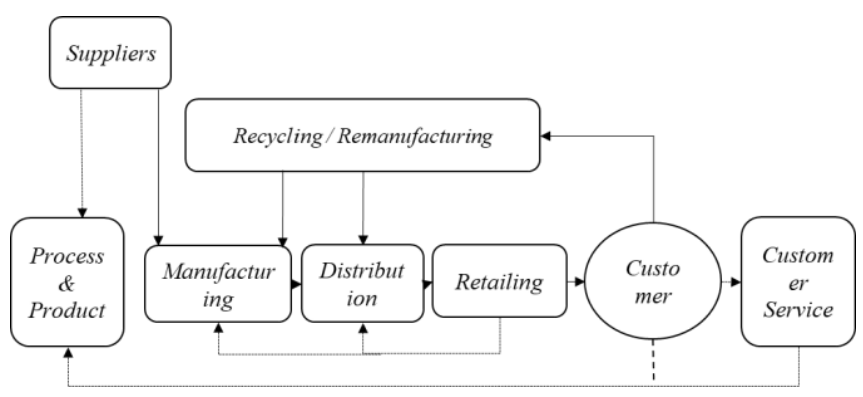

Fig. 4. Supply Chain Chart. Source: James A. and Mona J. Fitzsimmons (2006).

"Supplier, manufacturing, distribution, retailing, and recycling/remanufacturing" associated arrows and represents the material flow and the level of inventory in between each phase. The provision of information in the opposite direction is indicated by the dotted line and includes supplier activities, product development processes, and customer service. The manufacturing stage is a traditional process where raw materials come from external suppliers. Materials vary in many ways, adding value and creating finished product inventory. Other downstream levels, such as sales and retail, as well as increasing material value.

\section{Supplier Selection}

The selection of suppliers will generally give consideration to product quality, service and delivery. This is an important point, although there are various factors that must be taken into account. William J Stevenson, 2002: 701), The main factors that a company considers when choosing a supplier are as follows:

\section{Price}

That is the most important factor, if there is a discount, this will be even more important.

\section{Quality}

Some companies do not mind if they spend a lot of money to get good quality products.

\section{Service}

Special services are sometimes important supplier selection. Replacement of damaged goods, instructions for use of goods, repair of tools and similar services may be the key and more value to choose one supplier over another.

\section{Location}

When there is a sudden order or emergency service, the location of the supplier will affect delivery times, transportation costs and response times. Local buying can promote goodwill in relationships and help the local economy. The strategic location also provides added value, making it easier for customers to access.

5. Supplier inventory policy

If suppliers can maintain their inventory policies and maintain their spare parts, this will facilitate the need for raw materials.

\section{Flexibility}

The good intentions and expertise of suppliers in responding to requests and meeting design changes to orders can be an important factor in supplier selection

\section{Supplier Selection Criteria}

Gary W Dickson (1966) in the book I Nyoman Pujawan and Mahendrawati (2010:155), puts forward 23 criteria for supplier selection and evaluation. Because there are so many criteria for choosing suppliers, the criteria in the company are decided by the company itself. The company will choose various available standards, then the choice of standard usually depends on the raw material item provided to the company. The selection criteria for Diskson 23 suppliers are:

1. Quality;

2. Delivery;

3. Past Performance;

4. Warranty and Claim Policy;

5. Production Facilities and Capacity;

6. Price;

7. Technical Ability;

8. Financial Condition;

9. Procedural Fulfillment;

10. Communication System;

11. Reputation and Position in the Industry;

12. Business Passion;

13. Management and Organization;

14. Operation Control;

15. Service Repair;

16. Attitude;

17.Impression;

18.Packing Ability;

19.Labor Relations;

20. Geographical Location;

21.Prior Business Value; 
22. Training Assistance;

23. Reciprocal relationship.

\section{E. Definition of AHP Method}

Analytical Hierarchy Process (AHP) This is a decision support method by Thomas L. Saaty. This decision support model reflects a complex multi-factor or multi-standard problem as a hierarchical structure. Saaty (1993) believes that a hierarchical structure is defined as a representation of complex problems in a multi-level structure, where the first level is the goal, followed by factors, standards, substandards, and other levels, to the final alternative level.

The Analytical Hierarchy Process (AHP) is more widely used for problem solving than other methods for various reasons, namely:

1. Hierarchical structure to the deepest sub-criteria as a result of the selected criteria.

2. As a decision maker selection criteria and alternatives, consider the validity of the inconsistencies to the extent that is permitted. Considering the durability of decision output sensitivity analysis (Munthafa \& Mubarok, 2017).

\section{F. Stage Of AHP Method}

Kadarsyah and Ali (1998) said that the steps in the AHP method were (Munthafa \& Mubarok, 2017):

1. Define the problem then decide on the solution.

2. Develop a hierarchical structure starting from the main goal.

Generally, the hierarchical structure can be seen from Fig. 5 .

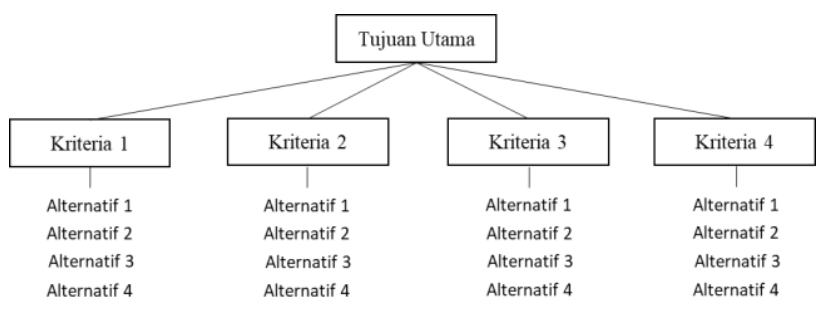

Fig. 5. AHP Hierarchical Structure.

3. Create a pairwise comparison matrix that will reflect the relative contribution of each element to the goals at the top level.

TABLE II. PAIRWISE COMPARISON MATRIX

\begin{tabular}{lcccc}
\hline \hline & Kriteria-1 & Kriteria-2 & Kriteria-3 & Kriteria-n \\
\hline Kriteria-1 & K11 & K12 & K13 & K1n \\
Kriteria-2 & K21 & K22 & K23 & K2n \\
Kriteria-3 & K31 & K32 & K33 & K3n \\
Kriteria-n & Kn1 & Kn2 & Kn3 & Kmn \\
\hline \hline
\end{tabular}

4. Determine pairwise comparisons that get a total of $n x$ $[(n-1) / 2]$ raters, where $n$ is the number of elements being compared.

5. Perform the calculation of the eigenvalues then perform a consistency test. If the data obtained is inconsistent so that the data collection is repeated.

6. Steps 3,4 , and 5 are performed at each level of the hierarchy.

7. Measuring the value of the eigenvectors of each pairwise comparison matrix, namely the weight of each element for determining the priority of elements at the lowest hierarchical level to achieve the goal.
TABLE III: PAIRWISE COMPARISON RATING SCALE

\begin{tabular}{cc}
\hline \hline $\begin{array}{c}\text { Intensitas } \\
\text { Kepentingan }\end{array}$ & Keterangan \\
\hline 1 & $\begin{array}{c}\text { Kedua Elemen sama Penting } \\
\text { Elemen yang satu sedikit lebih penting } \\
\text { dari elemen lainnya } \\
\text { Elemen yang satu sedikit lebih penting } \\
\text { dari elemen lainnya }\end{array}$ \\
5 & $\begin{array}{c}\text { Elemen yang satu sedikit lebih penting } \\
\text { dari elemen lainnya } \\
\text { Elemen yang satu sedikit lebih penting } \\
\text { dari elemen lainnya }\end{array}$ \\
$2,4,6,8$ & $\begin{array}{c}\text { Nilai antardua nilai pertimbangan yang } \\
\text { berdekatan }\end{array}$ \\
Kebalikan & $\begin{array}{c}\text { Jika Aktifitas 1 mendapat satu angka } \\
\text { dibandingnkan dengan aktifitas j, maka j } \\
\text { memiliki nilai kebalikan dibandingkan i }\end{array}$ \\
\hline \hline
\end{tabular}

The calculation is carried out by adding up the values in each column to get a normalized matrix, then adding up the values in each row and dividing by the total elements to get the average. If $\mathrm{A}$ is a pairwise comparison matrix, the weight vector has the form:

$$
(\mathrm{A})\left(\mathrm{w}^{\mathrm{T}}\right)=(\mathrm{n})\left(\mathrm{w}^{\mathrm{T}}\right)
$$

can be approached by:

1) Normalize each column $\mathrm{j}$ in matrix A, until:

$$
\sum_{i}(i, j)=1 \text { sebut sebagai } \mathrm{A}^{\prime} .
$$

2) Calculate the average for each row $i$ in $A^{\prime}$ :

$$
W i=\frac{1}{n} \sum_{i} a(i, j)
$$

where wi is the i-th destination weight of the weight vector.

8. Check the consistency of the hierarchy.

Suppose A is a pairwise comparison matrix and $\mathrm{w}$ is a weight vector, so that the consistency of the w weight vector can be tested, namely:

1) Calculate: (A)(wT):

$$
t=\frac{1}{n} \sum_{i=1}^{n}\left(\frac{\text { elemen } k e-i \text { pada }(A)\left(W^{T}\right)}{\text { elemen } k e-i \text { pada } W^{T}}\right)
$$

Formula 1. Consistency of Weight Vector

2) Calculate the consistency index:

$$
\mathrm{CI}=\frac{t-n}{n-1}
$$

Formula 2. Index Consistency

3) The RIn random index is the average value of CI which is chosen at random on $\mathrm{A}$ :

TABLE IV: RIN INDEX

\begin{tabular}{cccccccc}
\hline \hline $\mathrm{n}$ & 2 & 3 & 4 & 5 & 6 & 7 & $\ldots$ \\
\hline $\mathrm{R} I n$ & 0 & 0,58 & 0,9 & 1,12 & 1,24 & 1,32 & $\ldots$ \\
\hline \hline
\end{tabular}

4) Calculate consistency ratio: 


$$
\mathrm{CR}=C I / R I_{n}
$$

- If $\mathrm{CI}=0$, the hierarchy is consistent.

- If $\mathrm{CR}<0.1$, the hierarchy is quite consistent.

- If CR $>0.1$, the hierarchy is very inconsistent.

\section{METHOD}

Researchers used several data collection techniques and the use of questionnaires in this study. This is done in order to get the primary data needed, the resulting data will be combined for analysis, to get good results. Sugiyono (2015) The method of data collection is a strategic stage in research, because the purpose of research is to obtain data.

Data collection techniques use techniques such as the following:

\section{1) Questionnaire}

The questionnaire was carried out by giving a series of questions or questions to the respondent to be answered by the respondent, Sugiyono (2015). In this study, the questionnaire was prepared using closed type questions, respondents were asked to choose answers from prepared questions, respondents gave an assessment of their attitudes by choosing the criteria that had been prepared. This questionnaire was distributed to 7 respondents:

TABLE V: NUMBER OF RESPONDENTS AT PT. XYZ (JAKARTA)

\begin{tabular}{ccc}
\hline \hline No & Department & Responden \\
\hline 1 & PPIC & 2 \\
2 & Purchasing & 1 \\
3 & Marketing & 1 \\
4 & Quality & 2 \\
5 & Engineering & 1 \\
& Jumlah & 7 \\
\hline \hline
\end{tabular}

\section{2) Focus Group Discussion (FGD)}

This is a data collection technique, usually carried out in qualitative research, with the aim of finding the meaning of a topic based on the understanding of a group. The FGD aims to prevent researchers from misinterpreting the focus of the research question. FGDs are discussion groups, not interviews. The distinguishing feature of the FGD method is not found in other qualitative research methods (interviews or in-depth observations), namely the interaction between researchers and information providers with information providers and research information providers (Sutopo, 2006). The FGD in this study was used as a data collection tool for the criteria that became a reference in the selection of suppliers. The FGD in this study was attended by all managers and assistant managers at PT. XYZ (Jakarta).

\section{RESULT AND DISCUSSION}

After obtaining the geometric mean of all respondents' answers, the next step is to calculate priority vectors and feature factors, then perform a consistency test. The priority vector is obtained by dividing it by the calculated number of standards, substandard or alternative. The characteristic factor is the result of the sum of the results of the priority vector multiplication and the sum of the pairwise comparison matrices. The next step is to perform a consistency test by calculating the consistency index (CI) based on the results of the previous feature factor calculation. After getting the consistency index (CI) value, proceed to calculate the consistency ratio (CR).

Consistency ratio is a parameter to check whether pairwise comparisons in the questionnaire are carried out and carried out consistently. If the results have a small agreement ratio value of 0.1 , then the results are classified as consistent. If the approval ratio is greater than 0.1 , the questionnaire should be revised or re-filled. After completing the meals, the weight of each standard is presented numerically and graphically. Table VI below shows the results of the calculation of the pairwise comparison matrix and the results of the consistency test at the criterion level.

TABLE VI: RESPONDENT DATA

\begin{tabular}{ccccccccccc}
\hline \hline \multirow{2}{*}{ No } & \multirow{8}{*}{ Criteria } & 1 & 2 & 3 & 4 & 5 & 6 & 7 & Geomean & \multirow{2}{*}{ Criteria } \\
\cline { 3 - 9 } & & 8,00 & 7,00 & 0,11 & 0,14 & 3,00 & 1,00 & 0,14 & 0,87 & Delivery \\
& Price & 8,00 & 0,25 & 0,14 & 0,14 & 0,20 & 1,00 & 7,00 & 0,66 & Company Condition \\
2 & Price & 0,13 & 7,00 & 0,14 & 0,17 & 5,00 & 0,33 & 0,17 & 0,48 & Service \\
3 & Price & 0,11 & 0,33 & 0,14 & 0,11 & 0,33 & 0,33 & 0,13 & 0,19 & Quality \\
4 & Price & 8,00 & 7,00 & 0,11 & 0,14 & 5,00 & 1,00 & 8,00 & 1,67 & Company Condition \\
5 & Delivery & 0,11 & 7,00 & 0,14 & 6,00 & 5,00 & 1,00 & 7,00 & 1,57 & Service \\
6 & Delivery & 0,11 & 1,00 & 0,20 & 0,11 & 0,20 & 1,00 & 0,13 & 0,25 & Quality \\
7 & Delivery & 0,11 & 5,00 & 5,00 & 6,00 & 5,00 & 1,00 & 0,13 & 1,40 & Service \\
8 & Company Condition & 0,11 & 2,00 & 5,00 & 0,11 & 1,00 & 1,00 & 0,13 & 0,55 & Quality \\
9 & Company Condition & 0,11 & 0,25 & 0,20 & 0,11 & 0,14 & 1,00 & 0,13 & 0,20 & Quality \\
10 & Service & 0,11 & & & & & & \\
\hline \hline
\end{tabular}

Source: Author (2021).

TABLE VII: RESUlTS OF PAIRWISE COMPARISON MATRIX BETWEEN CRITERIA

\begin{tabular}{|c|c|c|c|c|c|c|}
\hline Criteria & Price & Delivery & Company Condition & Service & Quality & Priority Vector \\
\hline Price & 1,00 & 0,87 & 0,66 & 0,48 & 0,19 & 0,12 \\
\hline Delivery & 1,15 & 1,00 & 1,67 & 1,57 & 0,25 & 0,19 \\
\hline $\begin{array}{l}\text { Company } \\
\text { Condition }\end{array}$ & 1,51 & 0,60 & 1,00 & 1,40 & 0,55 & 0,18 \\
\hline Service & 2,09 & 0,64 & 0,72 & 1,00 & 0,20 & 0,14 \\
\hline Quality & 5,33 & 0,25 & 1,81 & 5,11 & 1,00 & 0,37 \\
\hline Total & 11,07 & 3,36 & 5,86 & 9,55 & 2,18 & \\
\hline \multicolumn{7}{|c|}{ Calculate CR Criteria } \\
\hline Eigen & 5,15 & & & & & \\
\hline CI & 0,04 & & & & & \\
\hline RI & 1,12 & & & & & \\
\hline $\mathrm{CR}$ & 0,03 & & DNSISTENT & & & \\
\hline
\end{tabular}

Source: Author (2021). 
TABLE VIII: ITERATION-1

\begin{tabular}{ccccccc}
\hline \hline Criteria & Price & Delivery & $\begin{array}{c}\text { Company } \\
\text { Condition }\end{array}$ & Service & Quality & $\begin{array}{c}\text { Priority } \\
\text { Vector }\end{array}$ \\
\hline Price & 5,00 & 2,49 & 3,46 & 4,21 & 1,05 & 0,10 \\
Delivery & 9,41 & 4,06 & 5,67 & 7,29 & 1,94 & 0,18 \\
Company & 9,56 & 3,54 & 5,00 & 7,27 & 1,81 & 0,17 \\
Condition & 7,03 & 3,57 & 4,24 & 5,00 & 1,34 & 0,13 \\
Service & 24,35 & 9,49 & 11,24 & 15,70 & 4,06 & 0,41 \\
Quality & 2406
\end{tabular}

TABLE IX: ITERATION-2

\begin{tabular}{ccccccc}
\hline \hline Criteria & Price & Delivery & $\begin{array}{c}\text { Company } \\
\text { Condition }\end{array}$ & Service & Quality & $\begin{array}{c}\text { Priority } \\
\text { Vector }\end{array}$ \\
\hline Price & 136,79 & 59,90 & 78,45 & 102,01 & 26,28 & 0,10 \\
Delivery & 237,98 & 104,54 & 136,69 & 177,44 & 45,69 & 0,18 \\
Company & 224,02 & 99,07 & 129,30 & 167,18 & 43,05 & 0,17 \\
Condition & 176,92 & 77,59 & 101,98 & 132,44 & 34,11 & 0,14 \\
Service & 176,73 & 233,74 & 306,51 & 395,79 & 101,89 & 0,41 \\
Quality & 527,73 & & & & \\
\hline \hline
\end{tabular}

Source: Author (2021).

In Tables VII and VIII it can be seen that the iteration calculation pattern can bring up a new matrix with a new weight value for each subject. The iteration calculation continues until the first matrix and the matrix after the next iteration do not change the priority vector value. The final result can be seen in the priority vector quantity shown in Table VIII which shows the criteria with the highest value, namely the Quality criteria with a value of 0.41 then followed by delivery of 0.18 , the condition of the company 0.17 , service 0.14 then the price with a value of 0,10 .

The priority weighting results for each subject at the subcriteria level based on the results of the last iteration calculation matrix can be sorted as follows:

1) Price Sub-Criteria
a) Priority I: $\mathrm{H} 3=0.41$
b) Priority II: $\mathrm{H} 1=0.25$
c) Priority III: $\mathrm{H} 2=0.21$
d) Priority IV: $\mathrm{H} 4=0.14$

2) Delivery Sub-Criteria
a) Priority I: P3 $=0.42$
b) Priority II: $\mathrm{P} 4=0.23$
c) Priority III: $\mathrm{P} 2=0.22$
d) Priority IV: P1 = 0.13

3) Sub-Criteria Condition of the Company
a) Priority $\mathrm{I}$ : KP1 $=0.41$
b) Priority II: KP3 $=0.38$
c) Priority III: KP2 $=0.21$

4) Service Sub-Criteria
e) Priority I: PL2 $=0.47$
f) Priority II: PL4 $=0.22$
g) Priority III: PL1 $=0.21$
h) Priority IV: PL3 = 0.10

5) Quality Sub-Criteria
i) Priority I: $\mathrm{K} 1=0.65$
j) Priority II: K3 = 0.23
c) Priority III: $\mathrm{K} 2=0.12$

Based on the overall results of the analysis presented in the research results section, using the Analytical Hierarchy Process (AHP) method, it can be concluded that the supplier selection criteria at PT. XYZ (Jakarta) in selecting its supplier selection will give priority to its main criteria for Quality criteria (Good quality of goods, Good packaging of goods,
Providing guarantees/guarantees) with a weight of 0.37 , then the second criterion, namely Delivery (On time delivery, Prevention of Damage, Order Conformity, Accuracy Amount of goods) with a weight of 0.19 , the third criterion is Company Condition (Experience and Background, Certified, Financial Capability) with a weight of 0.18, the fourth criterion is Service (Speed of response to outstanding, speed of response to complaints, speed of trial results, providing data) with a weight of 0.14 and the fifth criterion, namely Price (Competitive Prices, Negotiations, Payment Methods) with a weight of 0.12 . The results of this test can be used as a reference that quality is the most important indicator for PT. XYZ (Jakarta) in the selection of business partners or suppliers. Quality criteria used in this study includes three sub-criteria are based on the calculation results by using Analytical Hierarchy Process (AHP), of the three sub-criteria, sub-criteria K1 (Quality of goods both) into sub-criteria with the highest points with a weight of 0.67 . These results can be used as a reference that quality is the main criterion for the selection of suppliers at PT. XYZ (Jakarta) Jakarta

The price criteria used in this study include 4 sub-criteria based on the results of calculations using the Analytical Hierarchy Process (AHP) method, of the four sub-criteria, sub-criteria H3 (Payment Method) becomes the sub-criteria with the highest point with a weight of 0.41 .

Criteria Delivery is used in this study includes 4 subcriteria are based on the calculation results by using Analytical Hierarchy Process (AHP), of the four sub-criteria, sub-criteria P3 (Compliance Order) into sub-criteria with the highest points with a weight of 0.39 .

Criteria condition of the company are used in this study includes three sub-criteria are based on the calculation results by using Analytical Hierarchy Process (AHP), from the three sub-criteria, sub-criteria KP1 (Experience and background) into sub-criteria with the highest point with a weight of 0.41 .

Criterion service used in this study includes 4 sub-criteria are based on the calculation results by using Analytical Hierarchy Process (AHP), of the four sub-criteria, sub-criteria PL2 (speed of response to complaints) into sub-criteria with the highest point with a weight of 0.47 .

TABLE X: CONSISTENCY TEST RESULTS

\begin{tabular}{ccc}
\multicolumn{3}{c}{ TABLE X: CONSISTENCY TEST RESULTS } \\
\hline Paired Matrix & CR & Keterangan \\
\hline Main Criteria & 0,033 & CONSISTENT \\
Sub Criteria - Price & 0,020 & CONSISTENT \\
Sub Criteria - Delivery & 0,041 & CONSISTENT \\
Sub Criteria - Company Condition & 0,010 & CONSISTENT \\
Sub Criteria - Service & 0,009 & CONSISTENT \\
Sub Criteria - Quality & 0,003 & CONSISTENT \\
\hline \hline
\end{tabular}

Source: Author (2021)

In Table IX the results of the consistency test below have summarized the overall results of the calculation of the consistency test in this study showing that all respondents' answers fall into the consistent category so that the results of the study can be declared appropriate or valid. 


\section{CONCLUSION AND SUGGESTION}

\section{A. Conclusion}

Prior to the research, it was known that the supply chain process in the process of ordering to suppliers on the general criteria used in supplier selection was price, but after the results of the research it can be shown that the management of PT. XYZ (JAKARTA) prioritizes quality (good goods, packaging, warranty) compared to price, this is indicated by the results of the quality criteria assessment which are in the first priority with a weight of 0.41 while the price criteria are in the fifth priority with a weight of 0,1 . And the main factors for the selection criteria for suppliers at PT. XYZ (JAKARTA) is grouped into 5 factors, namely price, delivery, company condition, service and quality.

The supplier selection process at PT. XYZ (JAKARTA) using the AHP method places Quality criteria as the main criteria in supplier selection, then followed by Delivery, Company Conditions, Service and Price occupying the last position of the five predetermined criteria. By applying the results of this study at PT. XYZ (JAKARTA) Jakarta, is expected to be able to improve and develop supply chain processes at PT. XYZ (JAKARTA) Jakarta, so that it can be considered as a reference in improving Standard Operations in the Procurement division in determining suppliers.

\section{B. Suggestion}

Based on the results of this research, PT. XYZ (JAKARTA) is expected to examine the results of this research and be able to prioritize quality criteria (good goods, packaging, warranty) in supplier selection and followed by other criteria. With the hope that it will have an impact on the level of consumer satisfaction which will greatly affect the company's image and competitiveness. And if necessary, in the future, if there are factors or criteria that are more relevant to the company at that time, the company can change the criteria and sub-criteria or alternative suppliers, then recalculation can be done using the Analytical Hierarchy Process method. In addition to the selection criteria for the main supplier or vendor and sub-criteria, companies can also use the Analytic Hierarchy Proces (AHP) method for solving problems related to the best determination of an option that is multi-criteria or multi-alternative in other ways. as a reference to support decision making. $d$ with the acquisition of the criteria for selecting suppliers in this method, if management agrees with the results, PT. XYZ (JAKARTA) can evaluate existing suppliers.

\section{REFERENCE}

Astuti, P. (2016). Selection of Raw Material Suppliers Using AHP Method Case Study PT. Nara Summit Industry, Cikarang. Journal of Information and Communication Technology, 1(2), 27-36.

Belo, AM, Susetyo, J., \& Asih, EW (2017). Analysis of Raw Material Supplier Selection for Production by Using the Analytic Hierarchy Process (AHP) Method. Recreation Journal, 4(2), 67-72.

Dewi, Prima Maksi. (2019). Analysis of the Selection of Corn Starch Raw Material Suppliers for Creamer Production on Kopiko and Torabika Items Using the Analytical Hierarchy Process (AHP) Method (Case Study of PT. Mayora Indah TBK).

Hati, SW, \& Fitri, NS (2017). Analysis of the Selection of Npk Fertilize Suppliers Using the Analytical Hierarchy Process (AHP) Method. Inovbiz: Journal of Business Innovation, 5(2), 123-132.

Kusaeri, A., Hermansyah, M., \& Bashori, H. (2016). Supplier Selection Analysis using the Analytical Hierarchy Process Method Approach a
Pt. XX. Journal of Knowledge Industrial Engineering (JKIE), 3(2), 5161.

Limansantoso, MF, Management, J., Business, F., \& Economics, D. (2013). Selection of Calista Product Supplier Using Analytical Hierarchy Process (Ahp) Method at Pt. Buana Tirta Utama -Gresik. Calyptra: University of Surabaya Student Scientific Journal, 2(1), 1-20.

Makkasau, K. (2013). The Use of the Analytic Hierarchy Process (Ahp) Method in Determining Health Program Priorities (Case Study of Health Promotion Programs).J@Ti Undip: Journal of Industrial Engineering, 7(2), 105-112.

Munthafa, A., \& Mubarok, H. (2017). Application of the Analytical Hierarchy Process Method in the Decision Support System for Determining Student Achievements. Siliwangi Journal, 3(2), 192-201.

Novenius, Parasian Aditya. (2019). Supplier Performance Evaluation using the AHP (Analytical Hierarchy Process) method at PT. Sentosa Eternal Lamp.

Ngatawi, \& Setyaningsih, I. (2011). Supplier Selection Analysis Using the Ahp Method. Scientific Journal of Industrial Engineering, 1(1), 7-13.

Prayudy, Herdy. (2019). Application of Analytical Method.

Son, Eddie. Sutawijaya, Hidayat Ahmad. (2019). Analysis of Supplier Selection Criteria of Corrugated Box Packaging for The Pucuk Harum item with Analytical Hierarchy Process (AHP) Method, Jurnal Ilmiah Manajemen, 6(1), 121-138.

Putri, CF (2012). Selection of Suppliers for Packaging Raw Materials Using the Ahp (Analytical Hierarchy Process) Method. Widya Teknika, 20(1), 25-31.

Samosir, RS, \& Arvianto, A. (2019). Supplier Selection Using Analytical Hierarchy Process Method Assisted with Software Expert Choice 11 at Diana Bakery Semarang SMEs. Industrial Engineering Online Journal, 8(2), 10-15.

Sungkono, MA, \& Sulistiyowati, W. (2016 Perencanaan Dan Pengendalian Bahan Baku Untuk Meningkatkan Efisiensi Produksi Dengan Metode Material Requirement Planning Dan Analytical Hierarchy Process Di PT. XYZ, Spektrum Industri, 14(1), 1-108. 